\title{
The levels of antioxidants and some trace metals in Nigerians that are occupationally exposed to chemicals
}

\begin{abstract}
The levels of total antioxidants, vitamin $\mathrm{E}$ and certain trace metals ( $\mathrm{Mg}, \mathrm{Fe}, \mathrm{Zn}, \mathrm{Mn}, \mathrm{Cu}, \mathrm{Cr}, \mathrm{Cd}, \mathrm{Pb}$ and $\mathrm{Se}$ ) were determined in Nigerians who were occupationally exposed to chemicals for a period ranging from 16 to 20 years using colorimetric method and atomic absorption spectrophotometer respectively. In the automobile mechanics, the levels of chromium, cadmium and lead were significantly higher when compared with controls. In the motor painters, chromium and cadmium were significantly higher when compared with controls. Levels of manganese, copper, cadmium, lead and total antioxidants were significantly higher in panel beaters compared with controls. In the battery chargers, only total antioxidants were significantly higher compared with controls. The study shows that metal toxicity is imminent in panel beaters, automobile mechanics and motor painters and that the metals involved vary with occupations. This raises the need for public awareness about the hazards of different occupations in order to enable these professionals take necessary precautionary measures.
\end{abstract}

Key words: Antioxidants, chemicals, metals, nigeria, occupations

\section{INTRODUCTION}

Trace metals are essential micronutrients that are very important in the metabolic activities. Some trace metals are used as metalloenzymes (e.g., $\mathrm{Zn}, \mathrm{Fe}, \mathrm{Cu}$ and $\mathrm{Mn}$ ) for the synthesis of hormones (e.g., iodine) and as modulators in enzyme activities (e.g., $\mathrm{Cr}$ in insulin actions). ${ }^{[1]} \mathrm{Cu}, \mathrm{Zn}$ and Mn are important co-factors in the antioxidative activities of superoxide dismutase. ${ }^{[2]}$ Deficiencies of any of these micronutrients have been associated with certain disease conditions. ${ }^{[3]}$ Low level of chromium or its under-utilization has been linked with the causes of diabetes mellitus and glucose intolerance, while low level of zinc causes neural tube defect, anorexia and slow growth. ${ }^{[4]}$ Copper deficiency is attributed to anemia, low level of HDL cholesterol, while iron deficiency is one of the causes of anemia. ${ }^{[5]}$

Every trace metal is potentially toxic when present in high concentrations. This high level presence has been associated with prolonged exposure to the elemental sources in industries and polluted environments. ${ }^{[6,7]}$ Such high levels may cause displacement of another trace metal. Some transition metal ions (such as $\mathrm{Cu}^{++}$ and $\mathrm{Fe}^{3+}$ ) at toxic levels interact with superoxide radical to produce highly reactive and damaging hydroxylated free radicals which lowers the antioxidant status of an individual. ${ }^{[8]}$

Most Nigerians that are occupationally exposed to chemicals containing toxic metals are unaware of their side effects. Moreover, high levels of some of these metals may deplete antioxidants in the blood. Based on these two reasons, the present study determines the concentrations of certain metals $(\mathrm{Mg}$, $\mathrm{Fe}, \mathrm{Zn}, \mathrm{Mn}, \mathrm{Cu}, \mathrm{Cr}, \mathrm{Cd}, \mathrm{Pb}$ and $\mathrm{Se}$ ) and antioxidants (vitamin $\mathrm{E}$ and total antioxidants) in Nigerians that have been occupationally exposed to chemicals containing toxic metals for a long period (16-20 years).

\section{MATERIALS AND METHODS}

\section{Participants}

Twenty-one automobile mechanics, 11 automobile painters, 10 panel beaters and 8 battery chargers who had been on the profession for between 16 and 20 years were selected for this study. They were experts in the chosen field, having their workshops in Ibadan
O. G. Arinola, M. O. Akiibinu* Departments of Chemical Pathology and Immunology, University of Ibadan, Ibadan, and *Departments of Chemical Pathology and Haematology, Ogun State University, Ago-Iwoye, Nigeria

For correspondence: O. G. Arinola, Department of Chemical Pathology and Immunology, University of Ibadan, Ibadan, Nigeria.

E-mail: arinolaog@doctor.com

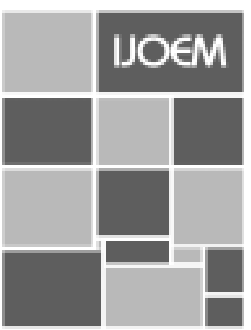


metropolis, Oyo state, Nigeria. Twenty (age- and sex-matched) controls were recruited from members of staff/students of University College Hospital, Ibadan, Oyo state, Nigeria. Informed consent was obtained form each subject before collecting blood samples. About $10 \mathrm{ml}$ of blood was collected from each of them into a sample bottle containing lithium heparin. The plasma was separated into another clean container before analysis.

\section{Determination of plasma levels of trace metals}

Plasma levels of these elements were determined with flame atomic absorption spectrophotometer (AAS) using a direct method as described by Kaneko. ${ }^{[9]}$ The method is based on the principle that atoms of the element when aspirated into AAS vaporized and absorbed light of the same wavelength as that emitted by the element when in the excited state.

\section{Determination of plasma level of total antioxidants}

Total antioxidant was determined by a method of Koracevic et al. ${ }^{[10]} \mathrm{A}$ standardized solution of Fe-EDTA complex reacts with hydrogen peroxide by a Fenton-type reaction, leading to the formation of hydroxyl radicals. These reactive oxygen species degrade benzoate, resulting in the release of thiobarbituric acid reactive substance. The rate of inhibition of color development is proportional to the concentration of antioxidative activity.

\section{Determination of plasma level of vitamin $\mathbf{E}$}

The level of vitamin $\mathrm{E}$ was determined in the plasma level by using the method of Baker and Frank, ${ }^{[11]}$ which is based on the principle that vitamin $\mathrm{E}$ extracted in xylene is made to react with alpha, alpha-dipyridyl. The product produces a reddish color with ferric chloride, which was read at $520 \mathrm{~nm}$.

\section{RESULTS}

Table 1 shows the mean levels of trace metals in different occupational groups compared with the controls. The mean levels of $\mathrm{Mg}$, Fe, $\mathrm{Zn}$ and Se were not significantly raised in motor mechanics, motor painters, panel beaters and battery chargers compared with controls. The mean levels of Mn and $\mathrm{Cu}$ were significantly raised in panel beaters compared with controls. The mean levels of $\mathrm{Cd}$ were significantly higher in mechanics, painters and panel beaters compared with controls. There were also significantly raised mean levels of $\mathrm{Cr}$ in mechanics and painters, while significantly high levels of $\mathrm{Pb}$ were found in mechanics and panel beaters when compared with the controls.

Table 2 shows the mean levels of ages (years), exposure (years), vitamin $\mathrm{E}$ and total antioxidants in mechanics, painters, panel beaters and battery chargers compared with controls. The mean levels of total antioxidants were significantly raised in panel beaters and battery chargers when compared with controls. The mean years of exposure and ages were similar in all the four occupationally exposed groups.

\section{DISCUSSION}

The implication of toxic metals in some professionals led to the quest to know the group/types of trace metals responsible for toxicity in affected individuals. The period of exposure of motor mechanics (17.5 \pm 1.6 years), painters $(19.6 \pm 0.8$ years), panel beaters (17.0 \pm 2.1 years) and battery chargers $(17.9 \pm 2.0$ years) were long enough to produce toxic effects in an individual.

In this study, levels of serum lead, chromium and cadmium were significantly high in automobile mechanics, while there were no significant changes in the levels of total antioxidants, vitamin $\mathrm{E}$ and other metals when compared with controls. Increased level of lead has been reported in the sera of automobile mechanics and highway workers. ${ }^{[12]}$ Employees

Table 1: Levels of trace metals in different occupationally exposed groups

\begin{tabular}{|c|c|c|c|c|c|c|c|c|c|c|}
\hline & $\mathbf{N}$ & $\underset{(\mathrm{mg} / \mathrm{L})}{\mathrm{Mg}}$ & $\begin{array}{c}\text { Fe } \\
(\mu \mathrm{g} / \mathrm{dl})\end{array}$ & $\begin{array}{c}\mathrm{Zn} \\
(\mathrm{mg} / \mathrm{L})\end{array}$ & $\underset{\text { (ng/dl) }}{M n}$ & $\begin{array}{c}\text { Cu } \\
(\mu \mathrm{g} / \mathrm{dl})\end{array}$ & $\underset{(\mu \mathrm{g} / \mathrm{L})}{\mathbf{C r}}$ & $\underset{(\mu \mathrm{g} / \mathrm{L})}{\mathbf{C d}}$ & $\begin{array}{c}\mathbf{P b} \\
(\mu \mathrm{g} / \mathrm{dl})\end{array}$ & $\begin{array}{c}\text { Se } \\
(\mu \mathrm{g} / \mathrm{dl})\end{array}$ \\
\hline Controls & 30 & $4.7 \pm 1.7$ & $69 \pm 15$ & $18 \pm 5$ & $51 \pm 18$ & $61 \pm 18$ & $47 \pm 19$ & $52 \pm 19$ & $39 \pm 15$ & $55 \pm 18$ \\
\hline Mechanics & 21 & $5.4 \pm 1.8$ & $70 \pm 19$ & $18 \pm 5$ & $61 \pm 20$ & $66 \pm 17$ & $58 \pm 20^{*}$ & $64 \pm 20^{*}$ & $50 \pm 17^{*}$ & $63 \pm 19$ \\
\hline Painters & 11 & $5 \pm 1.8$ & $69 \pm 14$ & $20 \pm 4$ & $59 \pm 15$ & $70 \pm 14$ & $61 \pm 16^{*}$ & $64 \pm 15^{*}$ & $46 \pm 16$ & $65 \pm 14$ \\
\hline Panel-beaters & 10 & $6 \pm 3$ & $75 \pm 33$ & $21 \pm 8$ & $68 \pm 34^{*}$ & $76 \pm 26^{*}$ & $61 \pm 27$ & $69 \pm 32^{*}$ & $56 \pm 25^{*}$ & $67 \pm 26$ \\
\hline Battery-chargers & 8 & $5 \pm 2$ & $67 \pm 15$ & $20 \pm 6$ & $58 \pm 15$ & $68 \pm 15$ & $59 \pm 15$ & $64 \pm 16$ & $44 \pm 18$ & $63 \pm 13$ \\
\hline
\end{tabular}

${ }^{*}$ Significantly different from the controls $(P$-values less than 0.05$)$

Table 2: Levels of vitamin $E$, total antioxidants and years of exposure to chemicals in different occupationally exposed groups

\begin{tabular}{lccccc}
\hline & $\mathbf{n}$ & Ages (years) & Exposure (years) & Vitamin E (mg/dl) & Total antioxidants (mmol/L) \\
\hline Controls & 30 & $32 \pm 5.0$ & & $10.8 \pm 1.5$ & $1.9 \pm 0.5$ \\
Mechanic & 21 & $34 \pm 2.3$ & $17.5 \pm 1.6$ & $10.1 \pm 1.1$ & $2.2 \pm 0.6$ \\
Painters & 11 & $32 \pm 3.5$ & $19.6 \pm 0.8$ & $10.3 \pm 1.0$ & $2.1 \pm 0.8$ \\
Panel-beaters & 10 & $35 \pm 3.0$ & $17.0 \pm 2.1$ & $11.1 \pm 1.3$ & $2.4 \pm 0.4^{*}$ \\
Battery-chargers & 8 & $32 \pm 7.0$ & $10.8 \pm 1.8$ & $2.4 \pm 0.7^{*}$ \\
\hline
\end{tabular}

${ }^{*}$ Significantly different from the controls $(P$-values less than 0.05$), n=$ Number of subjects 
working in automobile engine workshops were reported to be affected by toxic chemicals like lead fumes, carbon dioxide and benzene. ${ }^{[13]}$ It was also reported that chromium, lead and zinc are components of spare parts used in the vehicle construction industry, which could contribute to the levels of these metals in the sera of professionals having constant contact with them. ${ }^{[14]}$ Elevated concentration of hair chromium was reported in the tannery workers. ${ }^{[15]}$ High level of cadmium in exposed individuals may interfere with cerebral pyruvate metabolism $^{[16]}$ and this may lead to thiamine deficiency, emphysema and proteinuria in the occupationally exposed individuals.

High levels of cadmium, lead, copper, manganese and total antioxidants were observed in panel beaters. This is in support of the reports of Abdul Wahab ${ }^{[4]}$ that galvanized and ungalvanized iron pipe products used in mechanical industries and vehicle construction industry contain various types of metals like chromium, lead, zinc, copper, manganese and nickel ${ }_{i}$ the fumes of these metals may be inhaled during melting, ingested or absorbed (through the skin) when a panel beater constantly uses the metals for repair. High level of copper, observed in this study, has also been reported in active pulmonary tuberculosis ${ }^{[17]}$ as well as during pregnancy. ${ }^{[18]}$ Copper, manganese and zinc potentiate the antioxidant activities of superoxide dismutase ${ }^{[8]}$ which may contribute to high levels of total antioxidants observed in this study. Significantly high levels of cadmium and chromium were seen in motor painters selected for this study. Not too long ago, high levels of serum lead in painters (using leaded paints) and artists were reported. ${ }^{[6]}$ These lead-based paints have been abolished to avoid lead toxicity ${ }^{[6]}$ and this may account for the insignificant change in the level of lead observed in this study.

Occupation exposure to chromium has been reported in electroplating, steel making, leather tanning, photography, dyeing and chemical manufacture operations. ${ }^{[19,20]}$ Cadmium is a common pigment in organic-based paint and high levels of cadmium and bismuth compounds were detected in glass workers. ${ }^{[21]}$ Therefore, high levels of cadmium and chromium observed in these subjects are in agreement with these previous reports.

Similar levels of vitamin E and trace metals were found in both controls and the battery chargers, but there were significantly high levels of total antioxidants in these battery chargers. Previous workers reported high level of lead in the staff of battery assembly industry. ${ }^{[12]}$ The mean plasma levels of $\mathrm{Pb}$ in the battery chargers selected for this study were not significantly higher than in controls. It may be due to the fact that those battery chargers had no interaction with the lead electrodes inside the battery. The mean levels of total antioxidants were higher in occupationally exposed groups (especially battery chargers and panel beaters) compared with the controls. Antioxidants may be classified on the basis of their defense mechanism against free radicals ${ }^{[22]}$ - viz., primary antioxidants (superoxide dismutase, glutathione peroxidase, caeruloplasmin), secondary antioxidants (vitamin $\mathrm{E}$, vitamin $\mathrm{C}$, beta-carotene, uric acid, bilirubin and albumin) and tertiary antioxidants (DNA repair enzymes and methionine sulfoxide reductase). Nutritionally essential minerals ( $\mathrm{Cu}, \mathrm{Zn}, \mathrm{Fe}, \mathrm{Mg}$ and $\mathrm{Se}$ ) are not antioxidants until they are incorporated into the protective antioxidant enzymes. ${ }^{[22]}$

The significantly high levels of total antioxidants observed in this study might be a compensation for low vitamin $\mathrm{E}$ (another antioxidant) or response to raised toxic metals ( $\mathrm{Pb}$ and $\mathrm{Cd}$ ). Low levels of total antioxidants were reported in pulmonary tuberculosis, ${ }^{[23]}$ cancer $^{[22]}$ and pre-eclampsia. ${ }^{[24]}$

Certain trace metals (e.g., cadmium, copper and iron) at high plasma levels precipitate in muscles and viscera organs and that leads to damage of these organs. Anemia, neurological disorders, chronic renal failure, miscarriage, decreased gestational age and low birth weights have been attributed to lead toxicity. ${ }^{[25]}$ Some trace metals at toxic levels interact with superoxide radical to generate hydroxylated free radical that lowers the total antioxidants, with a resultant low immunity. ${ }^{[2]}$ Though the plasma concentrations of these trace metals in the affected professionals were below the toxic levels at the time this study was carried out, it may be speculated that automobile mechanics and panel beaters have the propensity to suffer from toxic effects of many other metals during prolonged exposure.

\section{REFERENCES}

1. Aspin N, Sass-Kortsak A. In: Disorders of Mineral Metabolism. Vol. 1. (Bronner T, Coburn JW, editors). Academic Press: New York; 1981 p. 59.

2. Preedy VR, Reilly ME, Mantle D, Peters TJ. Oxidative damage in liver diseases. J Intern Clin Chem 1998;10:16-20.

3. Dardenne M. Zinc and immune function. Eur J Clin Nutr 2002;56:5203.

4. Garry F. The Hair tissue Mineral analysis. The Trace Metals: 2001. p. 6-8.

5. Sreedhar B, Subramaniyan R, Nair KM. A protective role for zinc on intestinal peroxidative damage during oral iron repletion. Biochem Biophys Res Commun 2004;318:992-7.

6. Thomas PM. Toxic metals. In the Tietz Textbook of Clinical Chemistry, $3^{\text {rd }}$ ed. NB Saunders Co: Philadelphia; 1999. p. 982-98.

7. Fairhurst S. Hazard and risk assessment of industrial chemicals in the occupational context in Europe. Some current issues. Food Chem Toxicol 2003;41:1453-62.

8. Poli G. Liver damage due to free radicals. Br Med Bull 1993;49:604-20.

9. Kaneko JJ. Clin Biochem of Animal. $4^{\text {th }}$ ed. (Kaneko JJ, editor). Academic Press Inc: New York; 1999. p. 932.

10. Koracevic D, Koracevic G, Djordjevic V, Andrejevic S, Cosic V. Method for the measurement of antioxidant activity in human fluids. J Clin 
Pathol 2001;54:356-61.

11. Baker F. Clinical vitaminology: New York Willey; 1968. p. 172.

12. Artamonova VG, Pliushch OG, Sheveeleva MA. Several aspects of occupational effects of lead compounds on the Cardiovascular system. Meditsina Truda I Promyshlennaia Ekologiia 1998;12:6-10.

13. Chen D, Wu T, Yuan Y. A study on plasma non-species specific antibody in employees working in an automobile engine testing workshop. Zhonghua Yu Fang Yi Xue Za Zhi 1996;30:347-50.

14. Abdul-Wahab SA. Source characterization of atmospheric heavy metals in industrial residential areas: A case study in Oman. J Air Waste Manag Assoc 2004;54:425-31.

15. Lockitch G. Prospective on lead toxicity. Clin Biochem 1993;26:371-81.

16. Vallee BI, Ulmer DD. Biochemical Effects of mercury, cadmium and lead. In: Annual Review of Biochemistry 1972. p. 91-146.

17. Dareci F, Iihan N. Plasma Malondial hehyde and serum trace element concentrations in patients with active pulmonary tuberculosis. Biot Trace Elem Res 2003;95:29-38.

18. Anetor JI, Adelaja O, Adekunle AO. Serum micronutrient. levels, nucleic acid metabolism antioxidant defenses in pregnant Nigerians: Implications for fetal and maternal health. Afr J Med Med Sci 2003;32:257-62.

19. Shaw JC. Trace elements in the fetus and young infant. II. Copper, manganese, selenium and chromium. Arch Dis Child 1980;134:74-81.

20. Whenger PD, Ridlington JW, Holecomb CL. Interaction of zinc and selenium in the binding of CD to rat tissue proteins. Ann NY Acad Sci 1980;355:333-46.

21. Bachanek T, Staroslawska E, Wolanska E, Jarmolinska K. Heavy metal poisoning in glass worker characterized by severe. Ann Agric Environ Med 2000;7:51-3.

22. Khanzode SS, Muddeshwar MG, Khanzode SD, Dakhale GN Antioxidant enzymes and lipid peroxidation in different stage of breast cancer. Free Radic Res 2004;38:81-5.

23. Wiid I, Seaman T, Hoal EG, Benade AJ, Van Helden PD. Total antioxidant levels are low during active TB and rise with antituberculosis therapy. IUBMB Life 2004;56:101-6.

24. Raijmakers MT, Roes EM, Zusterzeel PL, Steegers EA, Peters WH. Thiol status and antioxidant capacity in women with a history of severe pre-eclampsia. BJOG 2004;111:207-12.

25 Michael JK, Charles EB. In: Basic and Clinical Pharmacology. Seventh edition. Appleton and Lange Stanford: Connecticut; 1998. p. 956.

Source of Support: Nil, Conflict of Interest: None declared.

\section{Author Help: Choosing an appropriate category of article for faster publication}

The manuscript system (www.journalonweb.com) allows the authors to check a likely publication date for a newly submitted article. Based on number of articles in review, number of accepted articles and acceptance rate, the system estimates the likely publication date for an article submitted on a given date.

If there are too many articles in a category e.g., case report, a newly submitted case report if accepted may have to wait for a long period before publication. Hence, the author can check other categories e.g. letter to editor or images, for such paper and submit to another category of articles. 